\title{
Nowe technologie na rynku kredytów konsumenckich, ze szczególnym uwzględnieniem pożyczek pozabankowych
}

\author{
New technologies on the consumer credit market \\ with the specific emphasis on non-bank loans \\ mgr Agnieszka Wachnicka
}

E-mail: wachnicka.agnieszka@gmail.com; nr ORCID ID: 0000-0002-0797-4073

\begin{abstract}
Streszczenie
$\mathrm{Na}$ przestrzeni ostatnich lat kredyt konsumencki przestał być domeną sektora bankowego. Wraz z postępem technologicznym na rynku kredytów konsumenckich pojawiają się nowe podmioty, zarówno udzielające kredytów i stanowiące bezpośrednią konkurencję dla banków, jak i podmioty pośredniczące oraz platformy umożliwiające zawieranie umów pożyczek bezpośrednio pomiędzy zainteresowanymi stronami. Silniejsza konkurencja przekłada się na większą różnorodność i dostępność kredytów, przeciwdziałając zjawisku wykluczenia finansowego oraz rozwoju szarej strefy. Rozwój nowych technologii wymaga jednak uwagi pod względem adekwatności regulacji chroniących interesy konsumentów, obserwacji zjawiska nadmiernego zadłużenia oraz cyberbezpieczeństwa.
\end{abstract}

Słowa kluczowe: : kredyt konsumencki, instytucja pożyczkowa, pożyczka pozabankowa, peer-to-peer lending, scoring

\section{Summary}

Consumer credit has ceased to be the domain of banks in recent years. Along with the technological progress new players have emerged on the consumer credit market, both granting credits and intermediating, as well as platforms enabling loan agreements to be concluded directly between the parties concerned. Stronger competition reflects in increased diversity and availability of credits, counteracting financial exclusion and the development of the shadow economy. However, the development of new technologies requires attention in terms of the adequacy of regulations protecting consumer interests, the observation of over-indebtedness and cyber-security.

Key words: consumer credit, lending company, non-bank loan, peer-to-peer lending, scoring

JEL: K15, O33

Str. $10-17$

\section{Bibliografia}

Główny Urząd Statystyczny. (2018). Działalność przedsiębiorstw pośrednictwa kredytowego w 2017 r. http://stat.gov.pl/obszarytematyczne/podmio-ty-gospodarcze-wyniki-finansowe/przedsiebiorstwa-finansowe/dzialalnosc-przedsiebiorstwposrednictwa-kredytowego-w-2017-roku,1,12.html (11.06.2019).

Jakubowska-Branicka, I. (red.). (2018). Rynek firm pożyczkowych w Polsce. Teoria i praktyka. Warszawa: Polskie Towarzystwo Ekonomiczne.

Klimontowicz, M., Harasim, J. (2015). Tendencje rozwojowe na rynku alternatywnych instrumentów finansowych. Annales Universitatis Mariae Curie-Skłodowska, XLIX(4), 227-235.

Kocoń, K. (2017). Prawnopodatkowe aspekty pozyskiwania kapitału w ramach finasowania społecznościowego przez mikro i małe przedsiębiorstwa (cz. 2). Finanse, Rynki Finansowe, Ubezpieczenia, 88(4), 207-218. 
Kondek, G., Ożarowska, E. (2018). InfoDOK: Raport o dokumentach. https://zbp.pl/getmedia/76f16600-5197-4ffa-a0f2b13fed789ff5/infodok-2018-10-12-wydanie-36-sklad-190127-gk5 (13.02.2019).

PBS. (2016). Badanie opinii publicznej „Jak Polacy zawierają umowy i rola dziennikarstwa ekonomicznego” przeprowadzone w związku z Nagrodą Dziennikarstwa Ekonomicznego Press Club Polska, na zlecenie Axa i Provident Polska. http://pressclub.pl/wp-content/uploads/2016/11/Jak-Polacy-zawieraj\%C4\%85-umowy-i-rola-dziennikarstwaekonomicznego.pdf, (07.02.2019).

Krajowy Rejestr Długów. (2018). Pokolenie $Y-$ (nie) dorośli do dlugów. https://krd.pl/Centrum-prasowe/Informacjeprasowe/2018/Pokolenie-Y--(nie)-dorosli-do-dlugow, (07.02.2019).

Rutkowska-Tomaszewska, E., Paleczna, M. (2018). Idea odpowiedzialnego kredytowania na rynku niebankowych kredytów konsumenckich w Polsce. Internetowy Kwartalnik Antymonopolowy i Regulacyjny, (6), 38-52.

Szpringer, W. (2017). Nowe technologie a sektor finansowy. FinTech jako szansa i zagrożenie. Warszawa: Poltext.

Utzig, M. (2015). Kredyty i depozyty bankowe gospodarstw domowych w Polsce na tle Unii Europejskiej. Handel Wewnętrzny (5), 395-409.

Wałęga, G. (2008). Regulacyjna rola państwa na rynku kredytów konsumpcyjnych w Polsce. W: Z. Dach (red.), Państwo a rynek we wspótczesnej gospodarce. Wybrane problemy. Kraków: Polskie Towarzystwo Ekonomiczne.

Wałęga, G. (2015). Zmiany w polityce kredytowej banków a zadłużenie polskich gospodarstw domowych. Konsumpcja i Rozwój, 10 (1), 44-55.

Związek Firm Pożyczkowych. (2013). Raport Mikropożyczki w Polsce. Pierwsze badanie produktów, kosztów i obstugi pożyczek internetowych.

http://static1.squarespace.com/static/51bf101ae4b010d205f86e84/t/5391fdc3e4b0dd94905fec79/1402076611218/Mikrop o\%C5\%BCycz-ki+w+Polsce.pdf (12.02.2019).

\section{Akty prawne}

Dyrektywa Parlamentu Europejskiego i Rady 2008/48/WE z 23.04.2008 r. w sprawie umów o kredyt konsumencki oraz uchylająca dyrektywę Rady 87/102/EWG (Dz.Urz. UE L 133, s. 66, ze zm.)

Rekomendacja $\mathrm{T}$ dotycząca dobrych praktyk w zakresie zarządzania ryzykiem detalicznych ekspozycji kredytowych (Dz.Urz. KNF z 2013 r. poz. 11).

Ustawa z 29.08.1997 r. - Prawo bankowe (Dz.U. z 2018 r. poz. 2187 ze zm.).

Ustawa z 12.05.2011 r. o kredycie konsumenckim (Dz.U. z 2018 r. poz. 993 ze zm.).

Ustawa z 5.08.2015 r. o zmianie ustawy o nadzorze nad rynkiem finansowym i niektórych innych ustaw (Dz.U. poz. 1357).

Ustawa z 23.03.2017 r. o kredycie hipotecznym oraz nadzorze nad pośrednikami kredytu hipotecznego i agentami (Dz.U. z 2017 r. poz. 819 ze zm.).

\section{Źródla internetowe}

http://www.credit-check.pl/wp-content/uploads/2018/06/Statystyki-2017.pdf (04.02.2019) 